Otto Saumarez Smith ${ }^{*}$ Lincoln College Oxford ${ }^{1}$

\title{
The Inner City Crisis and the End of Urban Modernism
}

\section{in 1970s Britain}

\begin{abstract}
This article links two processes that reached culmination during the 1970s: the emergence in central government of concern for inner city areas, and the rejection of urban modernist approaches to the built environment. It focuses on the approach of the Department of the Environment in dealing with the issue, particularly through the three Inner Area Studies on Lambeth, Small Heath in Birmingham and Liverpool 8, which were published in 1977. The first section gives an account of the background under which the Studies were commissioned by the Department of the Environment, then headed by Conservative Secretary of State Peter Walker. Part two gives a brief account of the Studies. Part three details their reception under the Labour Government, and shows their influence on the 1977 White Paper Policy for the Inner Cities. Through this case study two arguments are made about the changing approach to the built environment in the 1970s: that political and planning elites played a pivotal role in the disavowal of urban modernism in this period; and that the multiple problems exemplified by the inner city made modernist approaches appear increasingly untenable, even to former advocates. The conclusion suggests that, at least in its approach to the inner city, the meliorist aims of the post-war period were
\end{abstract}

\footnotetext{
* Guy Ortolano has been a generous and robust interlocutor at many stages in the drafting of this article. Warm thanks also to Simon Gunn, Peter Mandler, John Davis, Aaron Andrews, Richard Butler, Kit Kowol, Lucian Robinson, Louis Hellman and the anonymous reviewers. I gave an early version of this paper at the stimulating Rethinking Modern British Studies conference at the University of Birmingham in July 2015.
} 
not an intellectually spent force by the 1970s, but remained an ambitious and evolving project.

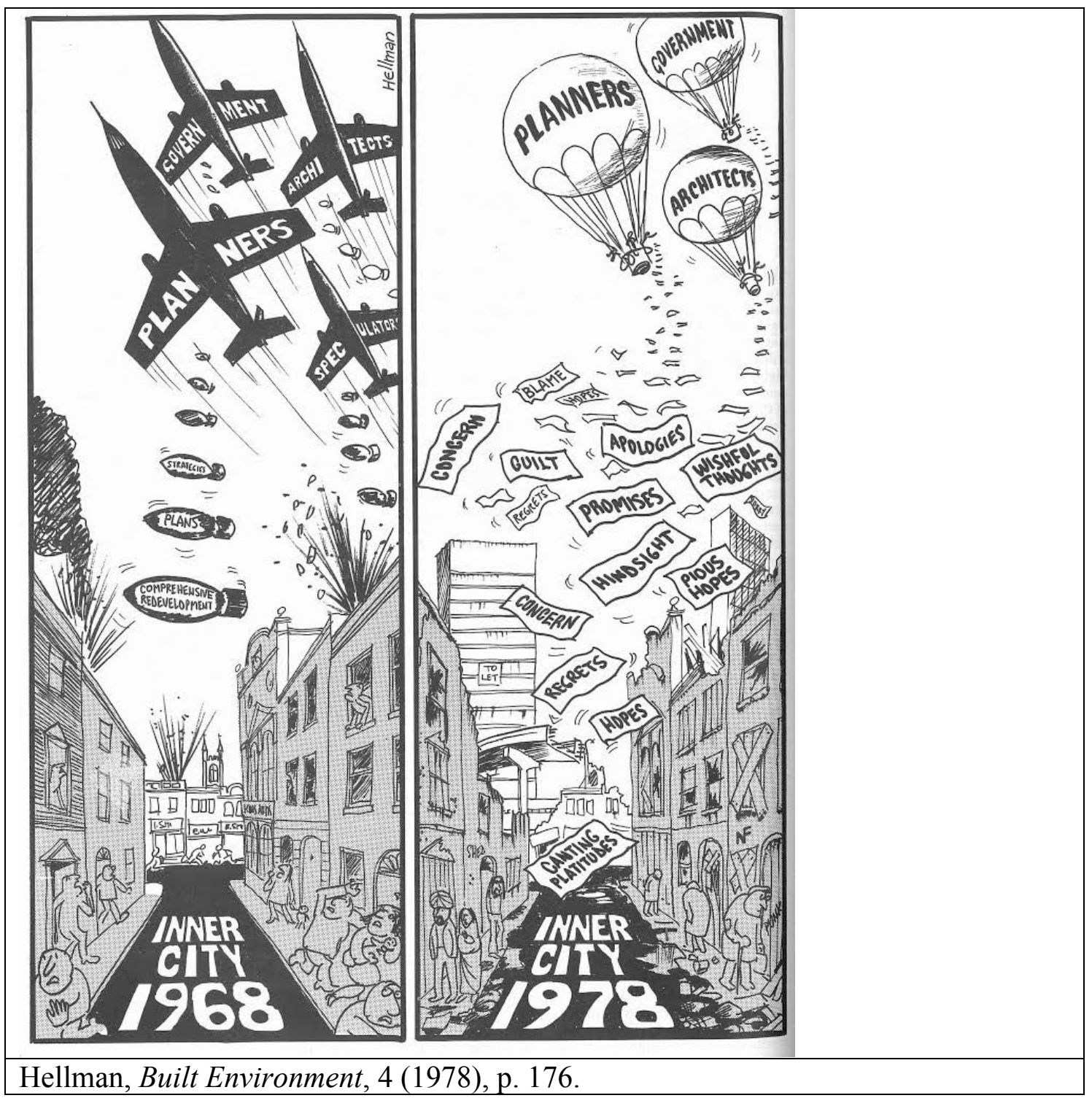

\section{Introduction}

In 1978 the architectural cartoonist Hellman deftly captured the profound volte face in approaches to the built environment that had occurred over the previous decade. A first image, titled 'Inner City 1968', shows four fighter jets labelled 'planners', 'government', 'architects' and 'speculators' offloading bombs titled 'strategies',

${ }^{1}$ E-mail: otto.saumarezsmith@history.ox.ac.uk 
'plans' and 'comprehensive development' on a traditional city, as people run for cover. In the second image the same scene is shown ten years later. The remaining houses are in a state of parlous decay, un-let office blocks loom over the scene, whilst a raised motorway ends mid-swoop, and a distant church spire is now in ruins. Over this bleak landscape of dereliction three hot-air-balloons - representing planners, architects and government - disgorge leaflets labelled with epithets of contrition: concern, guilt, hindsight, apologies, wishful thoughts, pious hopes and canting platitudes. One presumes the speculators' balloon did not have enough economic hotair to get off the ground.

In one sense the cartoon merely reinforces a narrative that is a commonplace of how we think about the period: that modernist orthodoxies in approaches to cities began to unravel from the mid-to-late 1960 s. $^{2}$ But in another way the cartoon suggests an unconventional way of reading this process - by suggesting that we reappraise who the protagonists of this switch were. The role of political elites, and of architects and planners, has been paramount in our understanding of approaches to cities in the 1960s, however when it comes to dealing with the period after modernism, the literature tends to focus on the emergence of public opposition to planning, especially through the conservation movement and various forms of community action. ${ }^{3}$ Clearly this represented an enormous and important change in the relationship between the state and society. In the early 1960s the most radical scheme could be passed with

\footnotetext{
${ }^{2}$ The very titles of many works on post-war British modernist urbanism speak of the centrality of a narrative trajectory of 'rise and fall', e.g. Simon Gunn, 'The Rise and Fall of British Urban Modernism: Planning Bradford 1945-1970', Journal of British Studies, 48:3 (2010), pp. 849-869; Lionel Brett The Broken Wave, the Rebuilding of England (London, 1981). On the early 1960s consensus over modernism see Otto Saumarez Smith, 'Central Government and Town Centre Redevelopment', The Historical Journal, 58.1 (March, 2015), pp. 217-244.
} 
barely a murmur. In contrast, during the 1970s opposition was widespread, instinctive and often well organised. ${ }^{4}$ Nevertheless, this has led to a rather manichean vision of the period, where the plucky St George of the conservation movement slays the implacable and monolithic dragon of the modernist establishment. This 'heroic' narrative has been compounded by the fact that history has often been written by protagonists of the conservation movement themselves. ${ }^{5}$ Such perspectives have obscured the way that modernist solutions were, largely independently, disavowed by the very planning and political elites who had been at the heart of the massive physical changes wrought on British cities in the 1960s. The presumption that cities would be totally transformed through urban renewal, radical architectural forms and policies of dispersal appeared increasingly untenable across the political spectrum, and from the perspective of former advocates as much as by long-term dissenters or reactionaries. Whatever its self-perception, the ubiquitous literature of hand-wringing polemic about modernism written during the 1970s ran in tandem with, and not in opposition to, official thinking at the time. ${ }^{6}$ The disavowal of urban modernism was pervasive.

\footnotetext{
${ }^{3}$ For example Christopher Klemek, The Transatlantic Collapse of Urban Renewal, Postwar Urbanism from New York to Berlin (Chicago, 2011); Alan Powers, Britain: Modern Architectures in History (London, 2007)

${ }^{4}$ Adam Sharr and Stephen Thornton, Demolishing Whitehall: Harold Wilson, Leslie Martin and the Architecture of White Heat (London, 2014), gives a localised example of this trajectory.

${ }^{5}$ For example: ed. Elain Harwood and Alan Powers, Twentieth Century Architecture 7: The Heroic Period of Conservation (London, 2004)

${ }^{6}$ Malcolm MacEwan, Crisis in Architecture (London, 1974); Lionel Brett, Parameters and Images (London, 1970); Colin Buchanan, The State of Britain (London, 1972), Tony Aldous, Battle for the Environment (London, 1972); Nicholas Taylor, The Village in the City (London, 1973); Colin Ward, Housing: An Anarchist Approach (London, 1976); Christopher Booker, The Neophiliacs: Revolution in English Life in the Fifties and Sixties (London, 1969) is a far from exhaustive list, but it is notable that many of these writers had themselves been modernist practitioners or fellow-travellers shortly before.
} 
The Hellman cartoon is also helpful for introducing another theme that this article will explore: that the inner city was a key arena in which the disavowal of urban modernism happened. ${ }^{7}$ In the 1970 s the concept of the 'inner city' became a spatially materialised locus for all that was perceived to have gone wrong with Britain's state and society in the post-war period. It was the physical location where many emerging anxieties that seemed so intractable in the period - about physical, social and economic decline, as well as issues ranging from race, to the persistence of poverty, to deindustrialisation - appeared manifest. The inner city was both exemplified by particular places, but was also understood as a sinister and creeping malady, 'a strange and foreign land set apart and ignored by society ${ }^{8}-$ a social concept made concrete in physical locations: 'The litany of place names is long and growing: Notting Hill in London, St. Anne's in Nottingham, Maryhill in Glasgow, Moss Side and Hulme in Manchester and Liverpool 8. But these are only the wellknown places, dramatized by events or documented in careful study. There are many other, still anonymous areas where similar conditions prevail. ${ }^{9}$ The problems of the inner city were nebulously and variously defined, so that in many ways it functioned to reflect back on people their own fears and neuroses - for those on the left it was a stark reminder of the systemic failure of capitalism and the continuance of grinding poverty, for those on the right it spoke of the fiasco of municipalisation and the breakdown of law and order. The inner city was the location where modernist solutions were seen most patently to have failed. The landscape of 'derelict industrial

\footnotetext{
${ }^{7}$ We might point to urban road building and city centre redevelopment as other key sites for this disavowal. John Davis, "Simple Solutions to Complex Problems': The Greater London Council and the Greater London Development Plan, 1965-1973', in Civil Society in British History. Ideas, Identities, Institutions (Oxford, 2003), 249274

${ }^{8}$ Des McConaghy, Another Chance for Cities SNAP 69/72 (Liverpool, 1972), p. 9.
} 
sites, abandoned docks, disused railway sidings, boarded up shops, empty warehouses and factories and vacant land', but also of 'vast new housing projects, slapdash and characterless, utilitarian and densely populated ${ }^{10}$, gathered a tremendous symbolic resonance, a visible image, as one report put it 'seen by many people only on their journey to work as they look down from the railway across the backs of terraces, or across the vacant land from main roads. ${ }^{11}$ This was not just about poverty, as coastal communities or Northumberland or Cornish mining villages might have as many signs of multiple deprivation - but these places did not have anything like the same visually located symbolic resonance. The inner city was a place where feelings of disillusion about modernism merged with widespread concerns about the perceived failure of Britain's social democratic project. It is impossible to understand the dissolution of urban modernism without understanding these broader shifts.

This article therefore aligns the pervasive narratives of crisis that were so central for how the 1970s were understood during the decade itself, with an equally pervasive architectural and planning narrative of the end of modernism. Both of these key historical categories, 'crisis' and 'modernism', need to be treated cautiously. It would be anachronistic to eschew them completely, as they were central to how the period was comprehended at the time; nevertheless, they obscure as well as illuminate much of what happened during the period. In common with recent scholarship on the political narratives of crisis in the 1970s, this article, without suggesting that a crisis was imagined, treats the reality of at least the more apocalyptic iterations of a

\footnotetext{
${ }^{9}$ Hugh Wilson and Lewis Womersley, Change or Decay, Final Report of the Liverpool Inner Area Study (London, 1977)

${ }^{10}$ Roger Barnard, 'Community Action in a Twilight Zone', RIBA Journal, October 1970 , pp. 445.

${ }^{11}$ Hugh Wilson and Lewis Womersley, Change or Decay, Final Report of the Liverpool Inner Area Study (London, 1977)
} 
supposed crisis agnostically. ${ }^{12}$ What the article does suggest is that a sense of crisis was conducive for new ideas and approaches. ${ }^{13}$

Modernism is a notoriously difficult term to define. ${ }^{14}$ In using the term 'urban modernism ${ }^{, 15}$ I aim to suggest both planning concepts - especially decentralisation, automobile-centred transport, planning blight, and slum clearance - but also architectural ones such as radical or high-rise forms, disregard for much of the existing historic fabric, a cannon of stylistic tropes, and industrialised building systems. Such a broad definition provides only a limited description of the nuances and variety of approaches to the built environment in the post-war period. ${ }^{16}$ The vast majority of building in Britain during the post-war period was neither radical nor particularly contentious: $85 \%$ of post-war housing stock had pitched roofs - only $6 \%$ had flat roofs. Even at the height of its popularity during the late sixties industrialised building systems only ever accounted for about 40\% of output. Between 1945 and 1976 a quarter of units were in terraces, a quarter detached, and just over a third semidetached. Of the mere $20 \%$ in flats most were not high-rise. ${ }^{17}$ Considerable things had

\footnotetext{
${ }^{12}$ Robert Saunders, 'Crisis? What crisis? Thatcherism and the Seventies', Making Thatcher's Britain (Cambridge, 2012), pp. 25-42; Colin Hay, 'Chronicles of a death foretold: The winter of discontent and the construction of the crisis of British Keynesianism', Parliamentary Affairs, 63 (2010) pp. 464-470; Camilla Schofield, Enoch Powell and the Making of Postcolonial Britain (Cambridge, 2013) pp. 264-272 ${ }^{13}$ Lawrence Black, Hugh Pemberton \& Pat Thane, eds., Reassessing 1970s Britain (Manchester, 2013) also stresses that a sense of crisis was conducive to new ideas, but focuses on the field of economics, and ideas emanating from the new left and new right, rather than from the political mainstream or in the field of urban policy.

${ }^{14}$ Guy Ortolano, 'Planning the Urban Future in 1960s Britain', The Historical Journal, 54.2 (2011), pp. 477-507, p. 506; Sarah Goldhagen, 'Something to Talk About: Modernism, Discourse, Style', The Journal of the Society of Architectural Historians, 64.2 (2005), pp. 144-167

${ }^{15}$ Simon Gunn, 'The Rise and Fall of British Urban Modernism: Planning Bradford 1945-1970', Journal of British Studies, 48:3 (2010)

${ }^{16}$ Elain Harwood, Space, Hope and Brutalism (London and New Haven, 2015); Guy Ortolano, 'Planning the Urban Future in 1960s Britain'.

${ }^{17}$ These facts all come from Simon Pepper, 'The People's House', Architectural Review, November 1977, p. 270-1.
} 
been achieved for those who had lived in overcrowded and unsanitary slums, slums that it would be wrong to romanticise. Much recent scholarship has also emphasised a less antagonistic relationship between modernism and conservation. ${ }^{18}$ These more everyday achievements of the post-war period's approach to the built environment became obscured during the 1970 s, as they continue to be obscured. The inner city was not the whole story of the British post-war environment, but it came to be representative, as it was in inner city areas that many of the most contested aspects of urban modernism occurred. There has recently been a surge of writing praising the tremendous aesthetic qualities and social intent of much post-war architecture. ${ }^{19}$ These positive aspects were tarnished and buried beneath a blanket rejection of modernism. But in attempting to rescue post-war buildings from idiotically vituperative scorn, historians shouldn't lose sight of the fact that it was a period with its mixture of the humane, the beautiful, the banal, and the catastrophic.

This article cannot answer the question of whether the more contested aspects of urban modernism created or exacerbated an inner city crisis. There are a huge array of reasons for the problem, many of which (notably issues of race and deindustrialisation) this article will only gesture towards, and cannot begin to objectively prioritize in order of importance. What it does argue is that the conception amongst political and planning elites that modernism had to some extent created the inner city crisis was a core reason for its rejection.

\footnotetext{
${ }^{18}$ Simon Gunn 'The Buchanan Report: Environment and the Problem of Traffic in 1960s Britain', Twentieth Century British History, 22.4 (2011), pp. 521-42; Otto Saumarez Smith, 'Graeme Shankland. A Sixties Architect-Planner and the Political Culture of the British Left'; John Pendlebury, 'Alas Smith and Burns? Conservation in Newcastle upon Tyne City Centre 1959-68', Planning Perspectives, 16 (2001), pp. 114-141.

${ }^{19}$ For example Elain Harwood, Space, Hope and Brutalism (London and New Haven, 2015); Barnabas Calder, Raw Concrete, The Beauty of Brutalism (London, 2016); Owen Hatherley, Militant Modernism (London, 2009)
} 
If one wants a single exemplar of the way that modernist solutions came to seem inadequate during the 1970 s, even to those who had been at the centre of radical sixties renewal, then the three Inner Area Studies offer a strong case study. These were commissioned from firms of architect-planners by the Department of the Environment in 1972, and were on Small Heath in Birmingham, Lambeth in London, and Liverpool 8. The final reports were published in 1977, but were the distillation of over eighty volumes of supporting research. ${ }^{20}$ As will be seen, they provided much of the theoretical and practical background for the approach of the 1977 White Paper Policy for the Inner Cities - the government's formal response to the perceived inner city crisis. The studies have received no extended attention by historians, although their importance was widely recognised and discussed at the time. ${ }^{21}$ The studies are just one sign of a pervasive upheaval in attitudes - but they are a particularly important manifestation of this upheaval, because of their demonstrable influence, and because of the insight they give on the attitudes of elites who had the power to enact changes of approach. They therefore give a valuable, albeit by no means an exhaustive, insight into this complex and poorly understood moment.

This article will follow these studies, from the background under which they were commissioned by the newly formed Department of the Environment under Edward Heath's Conservative government, through to their publication and reception under James Callaghan's Labour government. Though the Inner Area Studies account

\footnotetext{
${ }^{20}$ The supporting volumes can all be found in the British Library.

${ }^{21}$ There were a large number of books on the subject into the early eighties: The Future of the British Conurbations: Policies and Prescriptions for Change (London, 1980); J Edwards and R Batley, The Politics of Positive Discrimination: An Evaluation of the Urban Programme 1967-77 (London, 1975); The Crisis of the Inner City, ed. Martin Loney and Mark Allen (London, 1979); Inner City Regeneration (1982), p. 9; Peter Hall, The Inner City in Context (1981); Paul Lawless, Britain's Inner Cities, Problems and Policies (1981); Paul Lawless, Urban Deprivation and Government Initiative (London, 1979).
} 
for only one aspect of central government's wide ranging and cross-departmental approach to the issue, ${ }^{22}$ and only a tiny fraction of the vast literature on the subject produced in the period, paying attention to them will nevertheless show something of how and why the issue entered political discourse, gained a bipartisan momentum, and came to affect government policy. The article will also return to the theme of how this new constellation of issues called for new approaches, and helped to delegitimize the whole gamut of modernist approaches to the built environment that had been seen as established common sense just a decade before.

\section{I}

The Department of the Environment was a 'super department', formed in 1970 through merging The Ministry of Housing and Local Government, The Ministry of Transport, and The Ministry of Building and Public Works. In its very aggrandising structure it suggested the ambition towards a 'total approach' that would be such a keynote of the vocabulary surrounding inner area policy. As an institution it was keen to hit the ground running, full of dynamic civil servants open to new ideas, and run by Peter Walker, an enterprising and striving, yet still administratively inexperienced, Secretary of State, who felt he needed to prove himself following a meteoric rise after having benefited from the patronage of Heath, whose campaign manager he had been. ${ }^{23}$ The other headline result of Walker's tenure at Environment was the administrative county boundary changes following the Redcliffe-Maud report - which have been much lamented. An ungenerous account might posit that the Department of the Environment under Walker represents in microcosm the disappointments beset by

\footnotetext{
${ }^{22}$ The number of governmental schemes, often covering more or less the same ground and duplicating expense as well as effort, is boggling. Peter Hall and Inner Cities Working Party, The Inner City in Context (London, 1981) gives an overview. ${ }^{23}$ Peter Walker, Staying in Power: An Autobiography (London, 1991); Timothy Raison, The Tories and the Welfare State (London, 1990), p. 72-3
} 
the intellectually ambitious but ultimately ineffective and gimmicky Heath government. Alternatively a focus on Walker's approach to the inner city might be seen to contribute to an on-going construction of a more sympathetic portrait of the Heath government. ${ }^{24}$ Either way Walker accords little with either of the neat generalisations of the Heath government; too compassionate and too committed to government intervention to be understood as a proponent of Selsdon group Conservatism (even in these years before the 1972 u-turn), but hardly a 'hopeless wet' either. $^{25}$

During the 1971 summer recess Walker organised 'round table' discussions of officials at the Department's Training Centre at Cardington on the issues of 'A Total approach to Cities' and 'Improving the Total Environment'. ${ }^{26}$ It emerged that there was a dearth of information about inner city areas. As Walker retrospectively put it in a 1979 article, 'I quickly discovered that the realities of inner city life in Britain were relatively unknown to both local and central government... There were no plans to transform these areas. ${ }^{27}$ The Inner Area Studies would fill this gap in knowledge. In the speech in which he announced the reports to the House of Commons Walker already stressed that he conceived them as needing to break with approaches of the recent past, as 'long-term solutions are not much help to the people living in inner areas now: the blighting effect of longer term plans may make life worse for them in the meantime. 28

\footnotetext{
${ }^{24}$ Timothy Bale, The Conservative Party since 1945: The Drivers of Party Change (Oxford, 2012), p. 172-3

25 ibid.

${ }^{26}$ The National Archives (TNA), AT 80/7, Hillary Bauer, 'The Inner Area Studies', 14 February 1975.

${ }^{27}$ Peter Walker, 'A Conservative View', The Crisis of the Inner City, ed. Martin Loney and Mark Allen (London, 1979)

${ }^{28}$ Peter Walker, Parliamentary Debates (Commons), 833, 23 March 1972, 1689-727
} 
The commissioning of the Inner Area Studies can be linked to a trend that was recognised at the time as a 'rediscovery of poverty' in British public life, a process that was tied up with the end of the 1960s presumption that uninterrupted economic growth was eradicating most social problems. ${ }^{29}$ The Conservative Party's Policy Group on Areas of Urban Stress - which advised Walker - cited recent sociological surveys such as Coates and Silburn's study of the St Anne's neighbourhood in Nottingham, ${ }^{30}$ as well as the Halsey Report, Plowden Report and the National Child Development Study - as giving evidence that 'between two and four million people are probably still living below the so-called poverty line ${ }^{31}$ and subsequently resolving that this represented an imperative social task.

The Inner Area Studies were part of a succession of central government sponsored approaches to these issues. The educational priority areas in the 1967 Plowden Report were understood to have been the first sign of formal governmental awareness of the need for positive discrimination towards areas that had been 'left behind' by the affluent society. ${ }^{32}$ Despite coming under the aegis of the Department for Education, issues to do with poverty and the environment were seen as key by Plowden. Plowden was widely recognised as 'the single most easily identifiable landmark in this evolution of concern with areas of deprivation. ${ }^{33}$ Plowden was, however, only one of a number of government enquiries into many distinct subjects,

\footnotetext{
${ }^{29}$ On the rediscovery of poverty see Keith Banting, Poverty, Politics and Policy: Britain in the 1960s (London, 1979). The link between 'the rediscovery of poverty' and Walker's announcement was made in, amongst others 'Inner Cities: Dream and Reality', Community Action, No. 8 May - June 1973, p. 13-16.

${ }^{30}$ Ken Coates and Richard Silburn, Poverty: The Forgotten Englishmen (Nottingham, 1983)

${ }^{31}$ Conservative Party Archive (CPA): CRD 4/9/44, First draft of report of policy group on areas of urban stress. 14 November 1973.

32 Children and their Primary Schools (London, 1967)

${ }^{33}$ Hugh Wilson and Lewis Womersley, Change or Decay, Final Report of the Liverpool Inner Area Study (London, 1977), p. 2.
} 
which had been set up in the early 1960s and reported later in the decade, that came to similar conclusions. Milner Holland on London's Housing ${ }^{34}$ and Seebohm on personal social services ${ }^{35}$ also contributed to the shift of attention. The Home Office's sponsorship of the Urban Programme was the next major step. ${ }^{36}$ This was widely understood to have been part of the response to Enoch Powell's Rivers of Blood speech. $^{37}$

The Inner Area Studies were part of the switch of responsibility for dealing with inner city matters from the Home Office towards Environment, which solidified by 1976, when Peter Shore was given special responsibilities for 'Urban Affairs'. This was in large part a way of wresting the initiative away from a community driven style of the Community Development Project, which had been central to the approach of the Home Office's Urban Programme, but were seen, especially by the Conservative Party, as 'hunting grounds for the far left'. ${ }^{38}$ Many of the CDPs had 'adopted radical postures, increasingly seeing the problem in terms of the nature of capitalism and a mixed economy. ${ }^{39}$ In contrast, the Inner Area Studies were expected to 'emphasise questions of social structure and social change, but without the political

\footnotetext{
34 'areas in which bad housing is concentrated should be designated as areas of special control in which bad living conditions would be attacked comprehensively, assisted by an enlargement of powers', The Milner Holland Report, Housing in Greater London (1966)

35 'We are convinced that designated areas of Special need should receive extra resources, comprehensively planned...', The Seebohm Report, Local Authority and allied personal services (1969)

${ }^{36}$ For the way in which the Urban Programme developed out of the concerns of Plowden, particularly through the influence of the civil servant Derek Morrell, see Martin Loney, Community Against Government, The British Community Development Project 1968-78 (London, 1983), p. 44-5.

${ }^{37}$ Change or Decay, p. 3.

${ }^{38}$ Letter from Tim Raison, no date but c. 1973. CRD/4/9/13.

${ }^{39}$ TNA: AT $80 / 7$
} 
stance of the CDPs. ${ }^{40}$ The culmination of the CDP's Marxist analysis of the inner city problem was published in the same year as the Inner Area Studies. ${ }^{41}$ The CDPs saw anything short of revolutionary change as mere 'gilding the ghetto. ${ }^{, 42}$ Whether its argument that the inner city was a necessary feature of a capitalist economy was valid or not, it is perhaps not surprising that the revolutionary changes they advocated received little consideration by central government. ${ }^{43}$

The Tory focus on the inner city tied in with an ideal of compassionate Conservatism and was stressed, unsurprisingly, through the language of the lack of opportunity found in these areas, rather than in egalitarian terms. ${ }^{44} \mathrm{~A}$ focus on the inner city also resonated with the broad policy aim of focusing social services with greater selectivity, which had been a keynote of Tory thinking in their extensive policy formation carried out from $1966 .{ }^{45}$ It is arguable that, despite the frankly patrician tone, the 1970-1974 Conservative government was more actively committed to combatting poverty than their Labour predecessors had been. ${ }^{46}$ An argument often made was that these areas had been allowed to decline in part because the Labour Party - both centrally and at council level - were so confident of winning votes in these areas that they had become complacent and lacklustre, whilst resources had

\footnotetext{
${ }^{40}$ ibid. An expression of the types of worries Tories had with Community Development can be seen in the (CPA): CRD/4/9/13, 'Community Development', (12 December 1973), by 'ID/JW' (presumably Ian Deslandes).

${ }^{41}$ Inter-Project Editorial Team, The Costs of Industrial Change (London, 1977), p. 5.

${ }^{42} \mathrm{CDP}$, Gilding the Ghetto, the State and the Poverty Experiments (London, 1977)

${ }^{43}$ John Edwards, The Enterprise Culture and the Inner City (1993) argues that they did 'have an impact in the longer term'.

${ }^{44}$ CPA: CRD 4/9/44

${ }^{45}$ Rodney Lowe, 'The social policy of the Heath government', The Heath

Government 1970-1974 (London and New York, 1996), p. 194; For Walker's own articulation of this philosophy in regards to urban issues, see 'Peter Walker', Architects' Journal, 17 June 1970, p. 1490-1491.

${ }^{46}$ As argued by David McKay and Andrew Cox, The Politics of Urban Change (London, 1979), p. 247.
} 
been channelled into providing for the more affluent. ${ }^{47}$ When published, the Inner Area Studies gave some credence to this argument: in Liverpool for example, the consultants found that the $9.6 \%$ of city's population who were living in areas of multiple deprivation, did not even receive their fair share of the money available, but only $6.1 \%$ of resources.

As with so much in British urbanism, America was central, in large part because it was looked to as a forewarning of what was coming. The very term 'inner city' had been imported from America, and the 1965 race riots were regularly cited as a warning of what faced Britain if these issues were not tackled robustly. British inner cities presented 'a sinister caricature of the urban crises in the United States. ${ }^{, 48}$ As Conservative MP Timothy Raison ${ }^{49}$ warned: 'There is a real likelihood that if we allow conditions and standards in these areas to continue to degenerate (either absolutely or relatively to other parts of the country), we may land ourselves not only with human misery on a major scale but also with the sort of potential threat to the fabric of our Society which America has glimpsed in some areas in the past decade. ${ }^{50}$ From a political standpoint, it was considered difficult to present any programme as being mainly about helping immigrant communities specifically, as it was feared it would 'lead to a great deal of justifiable resentment'. ${ }^{51}$ Dealing with the inner city was therefore in many ways a semi-covert way to address issues of new immigrant communities. Although inner city areas and those with high concentrations of ethnic

\footnotetext{
${ }^{47}$ For example, Peter Walker, The Ascent of Britain (London, 1977), p. 127.

${ }^{48}$ Inner London, p. 2.

${ }^{49}$ Raison had edited New Society from 1964-68 before becoming an MP in 1970. New Society had been a hotbed for new thinking on urban problems in these years.

${ }^{50}$ CPA: CRD/4/9/13, Letter from Timothy Raison, May 14 [1973?], Conservative Research Department

${ }^{51}$ Conservative Party Archive (CPA), CRD/4/9/13, Conservative Research Department, 'Report of the Inner Cities Policy Group, letter 1 April 1974. Russell Lewis to Mr Bellairs.'
} 
minorities were not necessarily synonymous, Lambeth, Small Heath and Toxteth were areas notably affected by the issue.

An influence acknowledged by Walker was the Shelter Neighbourhood Action Project (SNAP) in the Granby area of Liverpool, which had highlighted that 'Relatively little, if any, resources had been deployed by the Ministry in facing those problems peculiar to the disintegration of our inner city areas. ${ }^{52}$ Walker visited SNAP both before and during his tenure at Environment. He hired SNAP's Des McConaghy as a consultant to the Department of the Environment on the studies. ${ }^{53}$ McConaghy, an 'unusually volatile man, with great energy and a sharp sense of humour ${ }^{54}$, had been an architect-planner with the Development Corporation of the Northern Irish New Town Craigavon before coming to SNAP. He saw a lack of the kind of organisation and effort directed towards the New Towns in the inner cities, where he found 'local groups, community councils and local government departments competing and grubbing around for a few hundred pounds here and there'. One of the things that might have endeared McConaghy to Walker, was his robust suspicion of 'those extremist factions which "home in" on such projects' (he was especially critical of radicals' poor dental hygiene!), and on a visit Walker was, according to McConaghy, able to 'observe that we were something less than the raving anarchists which could have been festing [sic] in his imagination.' SNAP's primary practical function was to enact a General Improvement Area in Granby, but out of this practical task the team developed a wide-ranging critique of the way these areas had been

\footnotetext{
52 Des McConaghy, Another Chance for Cities SNAP 69/72 (Liverpool, 1972), p. 146; See also the description of SNAP in Des Wilson, I Know it was the Places Fault (London, 1970), pp. 197-210

53 'Inner Cities: Dream and Reality', Community Action, no. 8, May - June 1973, p.

${ }^{54}$ Roger Barnard', Community Action in a Twilight Zone', RIBA Journal, October 1970
} 
approached in the past. Like the Inner Area Studies they stressed that post-war

modernist policies had exacerbated the problems:

The older cities are now memorials to the failure of intervention, which has resisted any positive social purpose. Not only has intervention failed, but subsidised commuter travel, urban motorways, urban renewal linked with new and expanded towns, ratesupport grants and many other forms of urban 'strategy' are all a vast subsidy to the suburban exodus leading to shortage of development opportunities beyond the city, under-utilisation of the city itself and formidable pockets of deprivation. So our failure to improve the quality of life in our older cities is complementary to the vigour with which we have accommodated every trend destroying the life chances of their remaining citizens. The eventual social costs implicit in the process have yet to be assessed. ${ }^{5}$

SNAP foreshadowed the approach of the Department of the Environment in several important respects, not just in the argument that modernist approaches had contributed to the problem. The Inner Area Studies would follow the move from practical action as a means towards research. SNAP noted that these areas needed a joined up total approach, and advocated 'Inner area agencies... dedicated to alleviating the misery of such areas, arresting their decline and reasserting their historic role as educators. ${ }^{, 56}$ Talking of Walker's announcement of the Inner Area Studies, McConaghy recognised that, 'It seemed generally as if the moves which were being taken coincided very happily with the type of programme which had been advocated by SNAP. ${ }^{57}$ The fact that SNAP was located in Liverpool is indicative of the centrality of that city to any discussion about the inner city and the irrelevance of modernist urban renewal approaches. Liverpool had been 'a testbed for a surprising

\footnotetext{
${ }^{55}$ Another Chance for Cities, p. 37.

${ }^{56}$ Another Chance for Cities, p. 146. The concept of cities as educators is from Max Weber.

${ }^{57}$ Another Chance for Cities, p. 147.
} 
number of the state's experiments. ${ }^{58}$ The desolation in the wake of Liverpool's botched slum clearance schemes was shocking. ${ }^{59}$

\section{II}

In commissioning three outside planning consultants to write reports on inner city areas, the Department of the Environment was doing what they typically did when confronted with a new perceived problem. The choice of consultants is nevertheless striking for having been drawn from the very cream of the modernist architect-planning establishment. ${ }^{60}$ It was exactly the same set of names, for instance, who had been picked by the Ministry of Housing and Local Government in the mid1960s for the second generation of new and expanded towns. ${ }^{61}$ Wilson and Womersley who took on Liverpool, had come from leading the most architecturally adventurous New Town, Cumbernauld, and the most architecturally adventurous local authority, Sheffield, and since joining together in a kind of modernist super group they had done such things as design Manchester's Hulme Estate and plan for the expansion of Northampton. Graeme Shankland and Oliver Cox who wrote the Lambeth report, with Peter Willmott, had started at the London County Council, joining together in private practice in 1965 . Their most significant project was the grandiose replanning of central Liverpool. ${ }^{62}$ Llewelyn Davis, Weeks, Forestier-

\footnotetext{
${ }^{58} \mathrm{CDP}$, Gilding the Ghetto, the State and the Poverty Experiments (London, 1977), p. 19.

${ }^{59}$ Change or Decay is almost apocalyptic in its description of these areas.

${ }^{60}$ The management consultancy firm McKinsey Inc. had been considered, but dismissed as too expensive and unable to display the range of experience of the architect-planners. TNA, AT 80/7, Hilary Bauer of Urban Affairs Division, 'The Inner Area Studies', 14 February 1975.

${ }^{61}$ See, Shankland Cox and Associates, Expansion of Ipswich (London, 1966); Wilson and Womersley, Expansion of Northampton (London, 1966); Wilson and Womersley, Northampton, Bedford, North Bucks Study (London, 1966); Llewelyn-Davies, Weeks, Forestier-Walker and Bor, A New City (London 1966)

${ }^{62}$ See Otto Saumarez Smith, 'Graeme Shankland: a Sixties Architect Planner and the Political Culture of the British Left', Architectural History, 57 (2014), pp. 393-422
} 
Walker and Bor, who took on Birmingham, are most famous for being the planners of Milton Keynes. ${ }^{63}$ It would be wrong to make bogeymen of these planners as such thumbnail sketches risk doing, and there were nuances in their approaches during the $1960 \mathrm{~s}$ - nuances that planted the seeds from which the new approaches of the 1970s could grow. ${ }^{64}$ Nevertheless, these were undeniably men who had been at the forefront of modernist renewal - envisioning cities utterly transformed through radical physical strategies.

If this continuity in personnel suggests a continuity in approach with an earlier period, this is belied by the contents of the reports, which foreground the failures of the post-war period and disavow modernist approaches and radical forms. A few examples stand out: The Lambeth study argued that 'Large-scale redevelopment... on the scale of the 1960s and early 1970 s is unjustified. Such programmes were unduly expensive and socially disruptive. They often involved the destruction of adequate houses and their replacement by dwellings which were poorer value for money.' On housing they argued, 'large new housing estates are usually an uncomfortable imposition upon the old street pattern' and even stressed the importance of Oscar Newman's concept of 'defensible space' - a concept that would become highly influential in the $1980 \mathrm{~s} .{ }^{65}$ Similarly the Liverpool study argued that the most successful and well cared for estates in the inner city were those "which are most like traditional private housing two and three storey blocks in staggered terraces or built around open squares... Those which have employed industrial building methods or

\footnotetext{
${ }^{63}$ Llewelyn-Davies, Weeks, Forestier-Walker, \& Bor, Unequal City: Final Report of the Birmingham Inner Area Study (London, 1977)

Walter Bor, The Making of Cities (Aylesbury, 1974)

${ }^{64}$ See Otto Saumarez Smith, 'Graeme Shankland: a Sixties Architect Planner and the Political Culture of the British Left', p. 393-6

${ }^{65}$ Oscar Newman, Defensible Space (New York, 1972); Ludovic Hunter-Tilney, 'Architecture: Paradise lost', New Statesman, 12 March 2012
} 
imposed extremes of architectural fashion are much less popular. ${ }^{, 66}$ This is a striking statement to come from the firm behind the megastructural Hulme Crescent flats in Manchester, only completed in 1972.

Charles Jencks famously started his book on post-modern architecture with the explosive statement that Modern architecture died on 'July 151972 at 3.32 (or thereabouts). ${ }^{97}$ I will not attempt to pinpoint such a precise point, but the writers of the Lambeth report were surely correct when they argued that 'These new doubts and queries did not arise overnight. The results of earlier policies took time to show themselves; the public reaction to immediate post-war measures, such as wholesale slum clearance, took more than a decade to make itself felt. ${ }^{68}$ The kernel of it can surely be pushed back into the mid-sixties. That the above statements - written by firms and under the aegis of a Department, all of which had been at the very heart of these very post-war changes - acknowledge these failures so clearly, albeit with little sense of mea culpa, is a remarkable indication of the significant reversal that had occurred during the previous decade.

The Inner Area Studies are indicative of a move away from a design-led approach towards a more holistic social approach: 'Traditionally, the improvement of inner city life had been seen as a physical task; clearing slums, removing industry and other so-called "non-conforming users" from residential areas, modernising the urban structure with new houses, schools, roads and other public services. But urban poverty remained. ${ }^{69}$ Though they were written under the direction of architect-planners, and although the original brief had largely been couched in terms of 'urban cosmetics',

\footnotetext{
${ }^{66}$ Hugh Wilson \& Lewis Wormersley Change or Decay, Final Report of the Liverpool Inner Area Study, (London,1977), p. 52

${ }^{67}$ Charles Jencks, The Language of Post-Modern Architecture (New York, 1984)

${ }^{68}$ Inner London, p. 3

${ }^{69}$ Inner London, p. 4
} 
barely a quarter of each volume is about housing or physical appearance - but takes in questions of people, jobs, incomes, community relations, problem families, welfare delivery, and regional planning. As a laudatory review by GLC planner David Eversley put it 'all three consultants managed to change the emphasis and accomplish the transition from physical to social planning. ${ }^{70}$ In contrast to the vast bulk of $1960 \mathrm{~s}$ planning, the reports focus on those who had not just been left behind by the meliorist project of social democratic Britain, but whose position was understood to have been exacerbated by the physical aspect of this project. They continued the move towards positive discrimination for areas that had been 'left behind' by the affluent society. In line with the intention that they would break with the radical critiques of the CDPs they were broadly Fabian and pragmatic in tone. Again quoting Eversley: 'There is no single ideological framework; scarcely veiled contempt for those extremists of the left or right who would save themselves the trouble of looking at the situation in minute detail by dismissing the collapse of the inner city as an inevitable structural failure of capitalism, or alternatively as the equally inevitable failure of inadequate families unable to show effort and initiative in getting out of their miserable situation. ${ }^{, 71}$ These are rich and complex sources distilling a mass of evidence. Each provides a vivid urban portrait. The Lambeth report especially has a high literary quality. They would sustain a much deeper analysis than is provided here. Although they disagree on several important points, and each took a distinctive methodological approach $^{72}$, it is nevertheless possible to sum them up as inaugurating a new philosophy and approach. This approach had five points. First, they reject a policy of

\footnotetext{
${ }^{70}$ David Eversley, 'London, The Inner Area Studies', Built Environment Quarterly, September 1977, pp. 172-3

${ }^{71}$ Ibid.

${ }^{72}$ David Hutchinson and Simon Gibbs, 'Inner areas: cultivating an important resource’ Architects Journal, 29 September 1976, pp. 583-584
} 
managed decline, which had begun to be mooted. ${ }^{73}$ Second, they foreground the need for a 'total approach', and added co-ordination between different agencies - showing greater sensitivity to the needs of local people. Third, they stressed that more money should be diverted towards the inner cities. Fourth, having identified the precipitous deindustrialisation in these areas they argued that the local economy, and especially the number of jobs, was the essential key to the revival of the inner cities. Last, a new approach was needed when it came to housing, and not just more of the same in terms of new building and municipalisation. These were all crucial arguments that would be debated, and acted upon, when the reports were released, under Callaghan's Labour government, and with Shore in charge at Environment. The 1977 White Paper on the Inner Cities advertised itself as the 'Government's response to the Inner Area Studies'. ${ }^{74}$ The White Paper in turn fed into the Inner Urban Areas Act of 1978.

\section{III}

The Labour Party's commitment to the inner city areas was in many ways more straightforward than that of the Conservatives. As Bernard Donoghue pointed out, Labour activists would 'instinctively support' a policy of 'massive effort to redistribute investment and redirect jobs and activity into the inner city areas improve public transport, restore the environment, and redevelop housing in an attempt to bring the quality of life and the level of economic activity up to those existing in typical outer zones. ${ }^{, 75}$ However, the flurry of concern about the inner city, which the Inner Area Studies were a significant part of engendering, came at a deeply

\footnotetext{
${ }^{73}$ For example, Joe Rogaly, 'Let the centres of cities wither away', Financial Times, 12 October 1976

${ }^{74}$ Cmnd. 6845, Policy for the Inner Cities (London, 1977)

75 TNA: PREM 16/921, 'The Inner City (Gen. 26), 2 August 1976. By Bernard [Donoghue]
} 
inauspicious moment - in the wake of the 1976 International Monetary Fund crisis, and severe cuts on public services.

Shore was in charge of the Department of Environment at the time. His tenure there has been widely criticised as having been ineffective - as his Oxford Dictionary of National Biography entry puts it 'by general consent he was far from dynamic in this post. ${ }^{76}$ His time at Environment was also overshadowed by the death of his twenty-year-old son in 1977 from a heroin overdose. Nevertheless, he did manage to keep the issue of the inner city alive at a time in which many Labour darlings were being sacrificed through the IMF cuts. Although there was already significant amount of talk of the need for private investment in the inner city ${ }^{77}$, the White Paper nevertheless achieved, with the 1978 Inner Urban Areas Act, an increase in Government spending on the Urban Programme from under $£ 30$ million to $£ 125$ million in 1979/80, as well as setting up partnerships between the Government and Liverpool, Birmingham, Manchester/Salford, Lambeth, and the Docklands.

The White Paper was preceded by discussion amongst a Ministerial Group on Urban Policies, chaired by Shore, but including many senior figures in the government, including Callaghan - who took a special interest in the need to 'look after the needs of the small firms displaced by land clearance in the inner cities. ${ }^{, 78}$ That the inner city remained something the government should be committed to was not entirely obvious. Perhaps surprisingly these arguments did not just come from Conservatives; Donoghue, for example made an illuminating comparison between the inner cities and declining industries: 'probably the more logical policy - to rationalise

\footnotetext{
${ }^{76}$ Martin Crick, 'Shore, Peter David, Baron Shore of Stepney (1924-2001)', Oxford Dictionary of National Biography (Oxford, 2004).

${ }^{77}$ Peter Shore, 'Private investment needed in inner cities', Chartered Surveyor, November 1978, p. 97-98

${ }^{78}$ TNA: PREM 16/921
} 
cities like old industries as they decline in population and attraction, closing down and cleaning up twilight areas as we do old coal mines, shipyards and docks. ${ }^{79}$ The White Paper, however, would make a number of arguments against such a position: it would be a waste of the considerable infrastructure and investment tied up in the inner areas; that central districts would suffer if the surrounding inner areas were left to decline; and that it was a more sensible place for development than areas on the outskirts.

The presumption that money should be diverted back into the old centres reversed one of the keystones of the post-war approach to cities, namely the dispersal of people and uses through policies of transport infrastructure, suburbanisation, and new and expanded towns. ${ }^{80}$ Shore's thinking on inner areas was bound up with his concurrent reappraisal of the New Towns. The announcement of the expansion of the urban programme to help inner cities was given symbolically in the same week as that the new town programme was to be cut back. ${ }^{81}$ In a dark economic climate, the money for the inner cities had to come from somewhere: 'Increased expenditure on programmes for inner areas can, in present circumstances, come only from a marginal redistribution of current resources, and this with difficulty. We shall need to see whether the new towns can help with this process. ${ }^{82}$ The White Paper concluded the need to 'change the thrust of the policies which have assisted large scale decentralisation. ${ }^{83}$

The White Paper built on long term trends in definitively moving central government's approach away from modernist reconstruction, seeing the central tool

\footnotetext{
79 TNA: PREM 16/921, 'The Inner City (Gen. 26), 2 August 1976.

${ }^{80}$ Andrew Saint, “'Spread the People': The LCC's Dispersal Policy, 1889-1965," in Politics and the People of London, The London County Council 1889-1965, ed. Andrew Saint (London, 1989)

81 'New towns and inner cities', Estates Gazette, 242, 16 April 1977.

${ }^{82}$ Peter Shore speech. 'Inner Areas and New Towns', no date but 1976. SHORE $11 / 38$
} 
for improvement as empowering local authorities to enact a Keynesian stimulus of jobs, alongside much more small-scale environmental interventions. The weight of public investment was to switch from redevelopment, the construction of housing and urban roads, towards public investment 'on a broader basis with emphasis on jobs, training, the environment and the improvement of existing housing.' It was stressed that in future there 'must be investment on a more human scale, with less disruption of community ties. ${ }^{84}$ The White Paper thus solidified the long-term move away from clearance towards rehabilitation ${ }^{85}$ : 'the rehabilitation of houses, coupled with environmental improvement and selective replacement, should normally be the practice rather than wholesale clearance schemes. ${ }^{, 86}$ Shore's distancing of himself from the modernist thinking of the 1960s was announced without ambiguity, especially when it came to housing:

when historians look back on the 'sixties I think they may categorise it as an age of illusion, of false hope and false dreams - a period in which we thought we could solve society's problems by turning to the new and untried, by breaking with the past. In no area is this more true than in the field of housing architecture where, with the best of intentions, though the worst of consequences, politicians, planners, architects - with few dissenting voices from outside - saw the block and other high density dwellings as the answer. This approach did answer one problem - slum clearance - for we saw a faster rate of planned redevelopment than any other country in the world. But I think we can now acknowledge that we probably created as many difficulties for ourselves as ever we solved. ${ }^{87}$

Talking with such declamatory vehemence about the 1960s was hardly unusual by the time Shore came to make this statement, and can be taken as representative of the

${ }^{83}$ Policy for the Inner Cities, p. 5

${ }^{84}$ Policy for the Inner Cities, p. 9

${ }^{85}$ Central Housing Advisory Committee, Our Older Homes: a Call for Action (London, 1966) had been an early sign of this switch. See Jim Yelling, 'The Development of Residential Urban Renewal Policies in England: Planning for Modernization in the 1960s', Planning Perspectives, 14 (1999) pp. 1-18

${ }^{86}$ Policy for the Inner Cities, p. 26

87 'Build to human scale: Shore', Architects Journal, 2 March 1977. 
ways in which the recent past was being constructed. ${ }^{88}$ It is notable that Shore, in common with many, saw architectural failure as indicative and representative of broader social, even moral, failures of a decade.

One common criticism of the White Paper was that the new commitment would only serve to superficially ameliorate the situation of the inner cities; 'gilding the ghetto' as the CDPs put it. ${ }^{89}$ Raison, in a perceptive and not unsympathetic pamphlet on the White Paper, echoed this critique, arguing that it might 'simply serve to maintain a situation in which things are neither quite bad enough to provoke anything drastic - be it revolution or vigorous self-help - nor good enough to banish the blight and squalor.' Nonetheless, Raison's central feeling that the White Paper represented a new commitment to tackling a major social problem is surely right: however much one may argue about the analysis and the prescription, it is entirely right that attention should have been focussed on the misery and squalor that pervade these decaying urban areas... Of course, we have been aware of the problem for at least a decade, and government has taken a number of steps in response to it. But these steps have not produced very much result, and the present commitment to action appears more whole-hearted than anything that has gone before. ${ }^{90}$

The White Paper was a document not only pointing towards a new era in its approach to the built environment, but also one coming at the twilight of a period of social democratic policies. This becomes clear as much from what it omits as what it includes. There is relatively little attention paid to traditionally right wing focuses on low motivation, personal responsibility, crime and vandalism, or policing; 'There is not a whiff of Samuel Smiles in it all. ${ }^{91}$ These were the themes that would become dominant in the rhetoric surrounding the inner cities in the 1980s. The 1979 election, although not immediately nor absolutely, fundamentally altered the direction of

\footnotetext{
${ }^{88}$ For example Christopher Booker, The Neophiliacs (London, 1970).

${ }^{89}$ Gilding the Ghetto (1977)

${ }^{90}$ Inner Cities the Right Programme?, p. 1

${ }^{91}$ Timothy Raison, Inner Cities the Right Programme? (1977)
} 
approaches to the inner city, meaning that we can only guess what the successes or failures of the approach heralded in 1977 might have been. ${ }^{92}$ In 1985 Faith in the City, by the Archbishop of Canterbury's Commission on Urban Priority Areas, called for a return to the approach of 1977 , which was 'as relevant today as it was nearly a decade ago ${ }^{, 93}$ : the White Paper's 'policy proposals have not been tried and found wanting. They have not been tried., ${ }^{, 94}$

\section{Conclusion}

In a 1976 speech on the inner city Shore linked recent progress in thinking with a mood of 'national self doubt'. He went on to say that: 'in one respect we have perhaps benefited from the national mood of self doubt - and that is in a willingness to accept that we may have made mistakes in the past. ${ }^{95}$ One of the things attractive about the responses to the inner city in this period is the way that they combine a vigorous debate about the failures of the recent past, with a cross-party commitment to finding ambitious and broadly redistributive answers. Though much of the rhetoric of this period is underlined by pessimism, in retrospect it also represented a brief moment of possibility; where the failures of the post-war period could be appraised and perhaps even tackled, but before new neo-liberal approaches which stressed personal responsibility and enterprise culture gained ascendency. ${ }^{96}$ The position of the inner cities got considerably worse in the early eighties, as the effects of monetarism speeded up processes of deindustrialisation and large-scale riots that had long been

\footnotetext{
${ }^{92}$ Although the Urban Programme itself had doubled to $£ 338$ million by 1985 . 'Inner Cities: Problems and Policies", 3 December 1985 CPA, CRD/B/11/4

${ }^{93}$ Archbishop of Canterbury's Commission on Urban Priority Areas, Faith in the City, A Call for Action by Church and Nation (London, 1985), p. 169.

${ }^{94}$ Faith in the City, p. 193.

${ }^{95}$ LSE Archive: SHORE 11/30 'Dealing with the Problems of Inner Cities and Housing, speech 3 November 1976 at Annual Conference of the National Housing and Town Planning Council at the Metropole Hotel, Brighton.'
} 
feared became a reality. ${ }^{97}$ At least in their approach to the inner city, the establishment that Thatcher overthrew was far more energetic and intellectually agile than tends to be portrayed. The meliorist ambitions of the welfare state generation were not a spent or moribund force during this period, but were part of an evolving, self-critical and robust project, still committed to using state intervention to help sections of society that had been left behind, and in a way that was alive to past failures. The historiography of 1970s politics understandably concentrates on the rise of Thatcherism, but this risks making what happened in the 1980s appear more inevitable than was in fact the case. Treating seriously the intellectual alternatives to Thatcherism that existed during the 1970s, as this article has done through a single issue, can suggest to us that there were viable alternatives.

${ }^{96}$ Nicholas Deakin and John Edwards, The Enterprise Culture and the Inner City (London and New York, 1993)

${ }^{97}$ Tackling the Inner Cities: The 1980s Reviewed, Prospects for the 1990s, ed. Susanne MacGregor and Ben Pimlott (Oxford, 1990) 